\title{
Infusing arts/multimedia into a secondary pre-service course on language and literacy across the disciplines as imaginative and critical practices
}

Anne-Marie LaMonde and Theresa Rogers, University of British Columbia

Inviting prospective teachers from disparate subject areas to think broadly and critically about literacy across the curriculum has been a decades-long struggle for literacy educators. As a means to imaginatively and critically engage pre-service teachers in a project to transform their notions of literacy, we conducted a three-year project (pilot plus two more years) that drew on arts-based and digital media learning to complement a mandatory literacy across the curriculum course for all secondary pre-service teachers at a major Canadian University. We began with a pilot project in one section of the course (taught by Anne-Marie) that resulted in a collaborative grant to support the infusion of arts-based and digital media approaches across the multiple sections of the course. In this paper, we will present the results, in traditional and video formats, of infusing this course with arts/multimodal learning opportunities relevant to various secondary school disciplines.

Background to the project

The purpose of this exploratory project was to experiment with extending and enhancing a content literacy course by infusing arts and digital media into the multiple (9) course sections through a series of workshops and course integration. The course (coordinated by Theresa) has traditionally taken a fairly standard "language and literacy across the curriculum for diverse settings" approach to encouraging subject area teachers to think about language and literacy as central to supporting students' academic success. 
As many secondary literacy teacher educators know all too well, this type of course is often met with resistance in teacher education programs. This resistance is often fuelled by a belief among secondary pre-service teachers that they are becoming content teachers and they should therefore focus on the transmission of that content (e.g. Alvermann \& Moore, 1991; Begoray, 2002; 2003). In this project, we attempted to ameliorate that resistance by sharing approaches to language and literacy that encompass a range of artsintegrated and multi-modal forms of representation and meaning making across subject areas.

Two previous investigations informed this project. The first investigation involved the theory and praxis of arts and media integration developed in a five-year investigation (2000-2005) with a one-year elementary pre-service cohort (FAME: Fine Arts and Media in Education). In this project, pre-service teachers were immersed in traditional and digital arts-based learning (Gouzouasis \& LaMonde, 2004; Gouzouasis. LaMonde \& Guhn, in press, 2007). A second study explored youth multiple literacies in an inner city alternative secondary school across three years (Rogers and Schofield, 2005; Schofield and Rogers, 2004; Winters, Rogers and Schofield, 2006).

These studies illustrated the ways in which arts-based and digital media can be successfully integrated across the curriculum to engage learners in imaginative and critical disciplinary and cross-disciplinary learning. The underlying model of learning deemphasises information and static knowledge in favour of more dynamic, critical and transformative learning across modes, genres, and social spaces (Rogers and Winters, 2006). In this work, we argue that sophisticated school literacy instruction includes a play 
of genre and media that engages even struggling students in the process of creating artsintegrated and digital expressions of voice, critique and social commentary.

We situate this project within a perspective that broadens notions of language and literacy across the curriculum to include the languages of music, visual art, drama/movement, and digital literacies as well as spoken language and print. These more recent notions of what constitutes language and literacy practices and ways of communicating across a variety of print and non-print media and genre are influenced by the work of the New London Group (1996; Cope and Kalantzis, 2000), and the semiotic work of Jewitt and Kress, 2003) on multimodal literacy, and by genre theorists (Bakhtin, 1986; Manovich, 2001) as well as the enduring work of researchers who have incorporated arts and semiotic theory into their research with children, such as Anne Dyson, Margie Siegel, Jerry Harste, and Cecily O’Neill (e.g. Siegel, 2006).

We argue that students live in an increasingly rich multimodal world, some would call a "mediasphere" which makes them potentially rich and critical consumers and producers of multimodal literacies as learning tools (Bean, Bean and Bean, 1999; Berghoff, 1998). Multimodal literacies "travel" across institutional boundaries (Leander, 2003) and provide a forum for students to become what Luke and Elkins (1998) refer to as "public intellectuals in new times." However, for a variety of reasons, schools continue to privilege print literacy over students' range of expertise in non-print environments (King and O'Brien, 2004).

We would also argue that the production of media, rather than relying on media criticism alone, invites adolescents to work within a range of genres, semiotic codes and gain understanding into how media shapes public discourse (Luke, 2002; Sefton-Green, 
2006), particularly when students are invited to identify how their work engages in and challenges dominant discourses (Poyntz, 2006). Rather than simply reproducing media, we have found in our work that both prospective teachers and adolescents often engage in playful ways to critique dominant discourses and, at times, oppose them.

Further, in our work, we hoped to avoid the scenario with new digital learning tools that Cuban describes in a current paper on the uncritical use of technology in educational settings. As Cuban (2006) notes:

Before there were computers, school policymakers had introduced film and radio in the 1920s, and instructional television in the 1950s as technological innovations to make teaching and learning faster and better. After they entered classrooms, researchers found there was initial excitement over how the innovation would revolutionize teaching and learning. Equipment was purchased and put into schools. Then researchers went into schools to see how often and in which ways teachers were using these technologies in lessons. They found very limited and unimaginative classroom use by teachers (p.1).

This project focuses on work with pre-service secondary teachers so that they might begin to experience the use of arts and multimedia to foster these new and imaginative approaches to learning across subject areas, and ultimately take some of the approaches into secondary schools. We recognize that this process relies on teachers and students working together and teaching each other new ways of expressing information and ideas in multimodal formats.

The project 
The pilot year

As we said earlier, this project was initially piloted in one section of the course. To provide a sense of the kinds of work student produced in that section, we provide a montage of the pilot year final films (to view them in full, see http://m1.cust.educ.ubc.ca:16080/ annemarielamonde/video1.htm)

\section{Click here to view - Pilot year video montage of final projects}

What is evident in the clips from these films: is the use by these pre-service teachers of the interplay of modes and genres (popular and classical music, a range of visual images, documentary, film and advertising genres) to imaginatively express knowledge in their disciplines and, in some cases, to use satire and parody to express critical views. We posit that until prospective teachers have a sense of what can be done with these approaches and how they and their students might draw on their cultural knowledge and resources (e.g. Kress, 2003; Luke, 2004), we will likely not see the full potential of arts and multimodal practices in schools.

After that pilot year course, Anne-Marie conducted email interviews with selected former pre-service teachers and received the following comments:

I was excited by the potential of video essays, musical performances, media scrapbooks and more. The course opened my eyes to all the ways we express our ideas: movement, speech, visuals, writing, etc. More importantly, it helped me to envision a classroom in which all these forms of expression have equal time.

As someone preparing to teach English and Social Studies, I was very focused on the written word. I now realize that language and communication skills extend beyond writing, that there are many forms of literacy (visual, 
media, consumer, etc.). The majority of these literacy forms are under-taught and under-encouraged in our current education system. I believe that to encourage students to develop multiple literacies can only contribute to their increased success in the classroom and in society.

I am currently teaching a group of kids that fall into the category of hating school. So variety that I can provide for them is great and this class gave me the tools and the confidence to try them.

The Main Project (Years 2 and 3).

The pilot study was followed by an additional two years of the project that included funding so that we were able to infuse these approaches across all 9 sections of the course, which included over 300 pre-service teachers. In year two, we collected data from several sources:

- Pre and post questionnaires about prospective teachers' views of language and literacy (see appendix one)

- An instructional implementation in the form of workshops, some of which were videotaped;

- Informal instructor feedback and

$\circ$ A follow-up focus group with four pre-service teachers.

In year three, we conducted in-depth interviews with selected instructors. 
The year two workshops.

Prior to the beginning of the course we offered the instructors an overview of the workshops that would be available to the pre-service teachers in the areas of "digital expressions" (video shorts); "text-integrated arts" (spoken word, soundscapes for storytelling, etc); and "virtual dialogues" (blogging, wiki). These overviews included reflections on, and examples from, the pilot study illustrating how these approaches could be implemented across disciplines in the secondary schools. All instructors selected at least one workshop for their pre-service class.

The digital expressions workshop. The digital expressions workshops included a pedagogical approach to creating video shorts and hands-on experience with acting, storyboarding, directing, filming, and editing. It also included the viewing of a montage of short video clips for use in critical thinking and responding in varied subject areas (e.g. animated shorts to illustrate social justice issues).

The video shorts aspect included an "inspiration" package with 4 artefacts as the basis for film teams to create four short film vignettes or an integration of the four artefacts into one film. The artefacts were a nursery rhyme, shapes to make with human bodies, interpretation of a sound, and a philosophical statement. The pre-service teachers self-selected their groups and were asked to participate in one or more aspects of digital filmmaking: writing, acting, directing, using the cameras, performing, composing, and film and sound editing (iMovie). They were encouraged to learn skills not previously experienced, e.g. filming, digital editing, or acting, to gain an understanding of digital technologies and social group dynamics. 


\section{Click to view Spiderman, Doves, and Humpty's Justice clips}

An interesting outcome of playing with the inspirational artefacts was the ways in which students manipulated genre. By downloading clips from YouTube, students created a "mashup" - that is, they inserted clips from films such as Spiderman, which were inter-cut with scenes of their acting to interpret their philosophical question: What is a hero? Sometimes students aptly played with visual imagery to symbolise love, such as in the Jack and Jill video, by capturing two doves walking on the campus ground. Often, students consciously orchestrated coherence between the four short scenes, which was not required for inclusion of the four artefacts, by stretching their artistic imagination. In the case of the video on Humpty Dumpty, which also had to address the notion of justice, the students mixed bodily shapes (i.e., hands) with the concept of the "hand of justice" (tied to the idea that Humpty's demise could find no justice) - a scene that bore both symbolism and satire. The workshop concluded with a reflection session to explore the use of film and video across disciplines. The use of video as an alternative mode for final projects was encouraged in most sections of the course, much like the films excerpted at the beginning of this paper. 

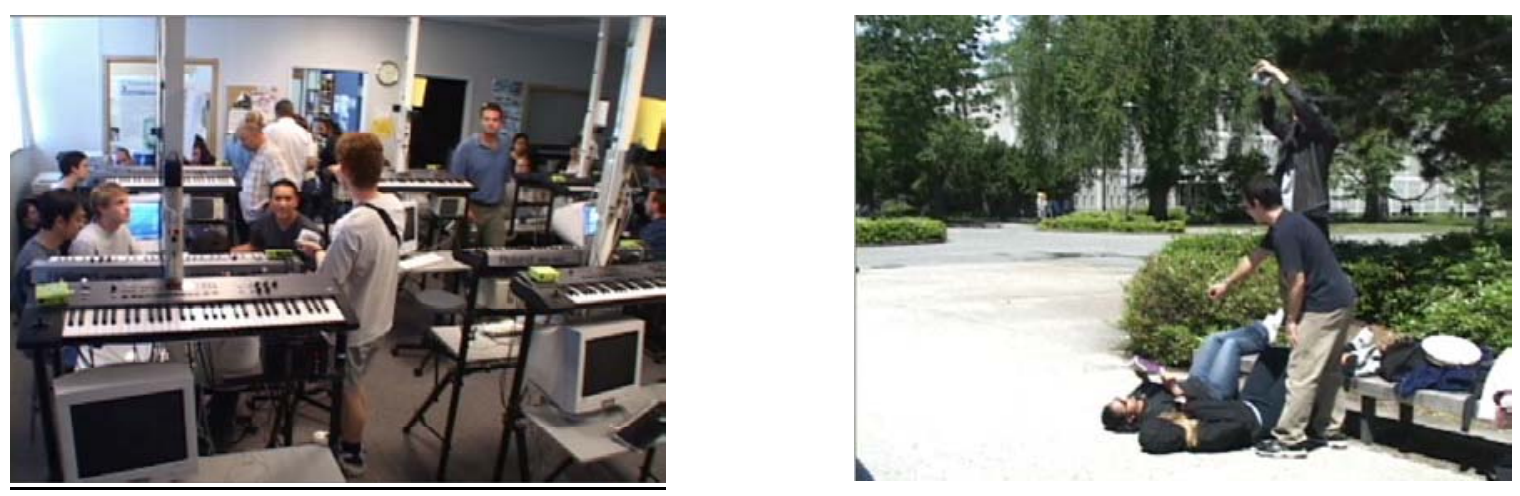

Prospective teachers filming and editing their videos

The text-integrated workshops. The text-integrated workshop on soundscapes explored how sound and music enhances poetry, speeches, short stories, and other improvised performances. Pre-service teachers listened to examples ranging from Leonard Cohen, to Monty Python, to spoken word artist Sage Francis (i.e. slam poetry). Students were then encouraged to use a variety of musical instruments to heighten the rhetorical effects of various texts (messages and emotions), through the use of sounds, together with movement and characterization.

We reflected on the workshop by sharing examples of integrating soundscapes across the curriculum. In the social sciences, soundscapes can be seen as echoes that punctuate the rhetorical devices and content of great speakers, or key historical events or underrepresented events could be re-enacted with soundscapes that underscore mood, tone, and tension. In the sciences, more traditional reports can be enhanced with soundscapes that emphasise the drama of content such as the movement of the cosmos or the reproduction of cells. 


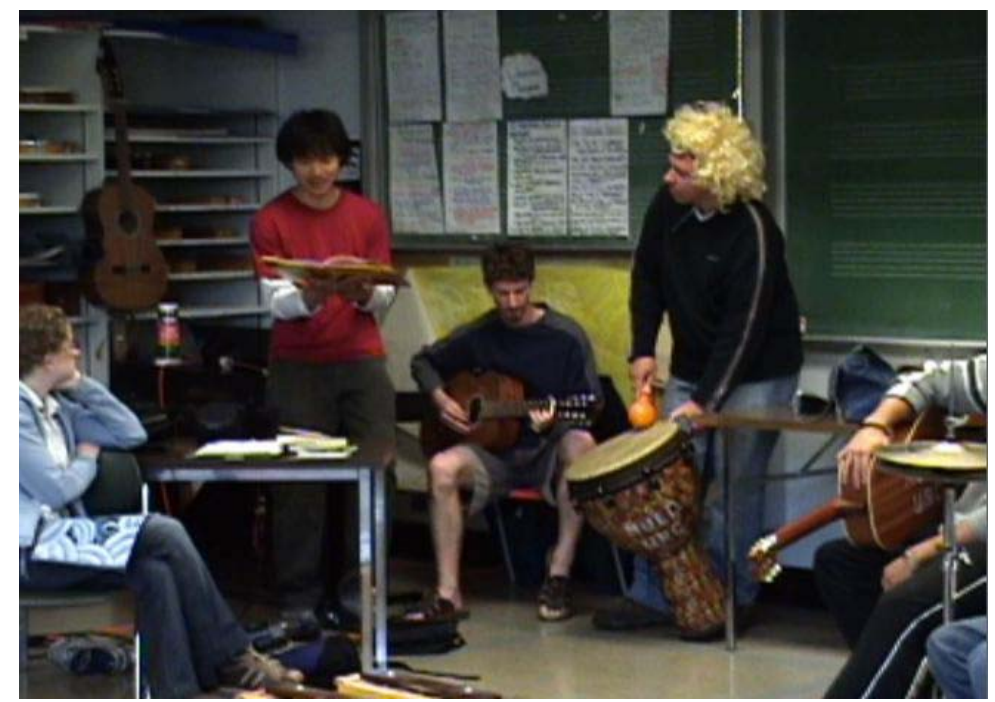

Soundscape workshop

The virtual dialogues workshops. These workshops focused on teaching students to create and use blog and wiki programs to dialogue with each other. Blogging, as a group activity, created extra time spent in deliberating issues outside of class. For instance, in one class, students were encouraged to read articles and to comment on inclass discussions or to write personal reflections. Some students chose to create personal blogs to extend assignments, a task that involved selecting a book and doing a reader response. One student created a blog as a viewer response to movies.

A sample dialogue from one section begins with the instructor commenting a student's own blog site in which a recent Time magazine article about technology was referenced. This began a critical dialogue about being in, and becoming teachers, in a "wired" generation:

Could technology take away our roles as teachers, or other professions? ...sometimes it scares me a little bit that I won't be able to keep up. The students will become the teachers.... Why do they love computers so much? 
This is an interesting comment reflecting the difficulty even for new teachers to let go some of their authority in a multimedia environment, and the need for them to allow the students to teach them as well.

Aww... the Internet ...is it not supposed to be creating a global community? I wonder what type of a community this really is? And who is fortunate enough to belong to it?

For me this blog has been difficult because, while we are "talking" with each other, it lacks the personal connection.

Is it just me or is there often a link between technology used in schools and corporate influences? The creator of Channel One news is currently in discussion about creating a money-making chain of private schools in the U.S. His current backers include Time Warner and Disney--just to name a few powerful names. His idea is to turn a profit by using volunteers and technology to teach classes, rendering the role of the classroom teacher obsolete! In his view, teachers (or at least our current school system) are failing kids anyways so why are we paying them? Are we really failing our kids or is that what large corporations would have you believe?

These blog entries illustrate a skeptical and, we feel appropriately critical, view of the kinds of multimedia interactions in the lives of students and teachers that might work against community building and the co-construction of new knowledge. And, to us, it is quite interesting that one student begins to questions the motivations of corporations that are employing technology in schools, suggesting that multimedia tools should be taken up by teachers in ways that imaginatively and critically engage students and teachers, lest 
they become be tools to dismantle a democratic system of education.

Responses from instructors and pre-service teachers

Year Two

Student questionnaires.

We gave questionnaires to all students in the course at the beginning and end of the six-week term, which asked for their definitions language and literacy, their views of the role of language and literacies in secondary schools and in their discipline, their views of arts and multimedia and learning, and their familiarity with these approaches and various digital technologies (see appendix one).

Over 250 questionnaires from students who consented to participate were collected. We analyzed a subset of 32 pre and post questionnaires across 4 sections completed by students who chose to identify themselves. The disciplines represented by these students included Science (12); Social Studies (7); English (7); Music (2); Art (1); Math (1); Physical Education (1); French (1); Home Economics (1).

By looking across their responses to questions before and after the course, we have documented several ways that their views changed. All 32 students began with "functional," "foundational" and "communication" views of literacy (e.g. reading and writing are essential to communication and to functioning in school and society). Two of those students commented also on the power of literacy in society. In addition to or replacing those comments in the post-test were comments about not only integrating print 
literacy across the curriculum, but also views of literacy as having multiple modes, genres, and expressive purposes.

Most students felt, prior to the course, that these approaches would support learning in their disciplines: 26 responded positively, 5 said maybe, 1 responded negatively. In the post-course survey, 31 responded positively, and the one negative respondent remained negative (this prospective physics teacher who did not expect to use multimedia in his teaching felt there was not enough "slack" in the curriculum to warrant these approaches and, at best, he would make them optional for students who already had the skills).

What was most interesting in the positive responses were the reasons students gave regarding the strength of arts/multimedia approaches. We categorized their responses into 5 major reasons they supplied for supporting these approaches and provide sample responses:

1) They are inclusive, supporting diverse learning styles and multiple intelligences, and addressing needs of special education students - 13 responses; iMovie media offers a different format for teaching practice as well as assessment of other "intelligences" like visual/special and interpersonal... and potentially build up confidence for students who are less verbal/logical.

2) They are engaging, motivating and dynamic -9 responses; [Videomaking technologies] are potentially interesting educational vehicles for engaging today's connected and interactive teenagers. School competes for the attention of learners with all manner of electronic media-iPods, movies, television, videos, electronic gaming. The delivery of scholastic materials through lectures, books, and 
discussion pales in comparison to the dynamic, colourful and visceral presentations of the competition....iMovies are a backchannel that might lead to the very same academic material which is covered in a more pedantic fashion on the classroom floor.

3) They support conceptual understanding -8 responses

This technology could be used successfully in all areas of the curriculum. For me, specifically, I think iMovie could be extremely useful in the field of social studies...to have students re-enact and interpret specific historical events.

4) They provide new forms of expression -4 responses Some concepts and ideas are difficult to express clearly with pen and paper but become much more accessible when presented through other media.

5) They encourage critical perspectives -4 responses.

Using drama, film, blogs is a great way for students to take on various historical perspectives and express their opinions.

These responses were consistently represented across all disciplines. For instance, while we might assume that conceptual understanding would be potentially more important than other aspects to most of the science majors, or that English teachers might be more interested in new forms of expression, this was not the case. Students also responded that they benefited from particular workshops, such as the digital expressions workshop, and were willing to entertain the idea of using arts and digital media in their subject areas to engage students in knowledge creation.

Limitations of our project are also evident in the questionnaire analyses. For instance, students wanted more time to reflect on ways to incorporate arts and digital 
media into specific disciplines in their teaching. They also noted that in some sections the ideas and tools presented in workshops were not necessarily extended through additional experiences in the course and in relation to their course assignments.

\section{Instructor comments}

In their comments, instructors were generally very enthusiastic about the new dimension to the course and they found that it lessened resistance to the idea of a language and literacy course for pre-service teachers in content disciplines. Their comments corroborated student comments on the importance of fully integrating these approaches into their course curriculum in the form of projects that support particular content areas.

\section{Click here to view Video clip of instructor interview}

The student focus group.

At the end of the term, we conducted an in-depth focus group with four students who elaborated and extended their questionnaire responses and responded to each other's experiences and reflections, and interviewed selected course instructors.

The rich feedback from the student focus group, which was filmed and transcribed, extends these new understandings. Several students noted, for instance, that this was their first encounter with this range of technologies in their teacher education program; anything they knew prior to this course they brought with them, but had not yet had an opportunity to include in their coursework. They also expressed an understanding of the significance of using these approaches in schools:

"Using different modes of expression as a teacher is as important as giving students the opportunity to express differently." 
"Why we insist on paper and pen as the primary sources in school doesn't make sense...especially when we've evolved [beyond that] in the workplace. To me, history is not static."

"I like the fact that there are new forms of communication coming into the system. These new forms are opening up possibilities that allow some of us to find alternate ways to communicate..."

"It's where we are headed now."

In general, the focus group students voiced their broad understandings of language and literacy practices and many concrete examples of possibilities for transforming their teaching from a limited sense of print-based information transmission to knowledge creation across multiple forms of representation. These included innovative uses of media literacy and web-based approaches with arts and multimedia -- they talked about critiquing visual images in artistic portrayals of war, developing an interactive Webbased project on The Diary of Anne Frank, creating a web-based game on career paths as related to socio-economic status, and incorporating drama into filmmaking to portray historical events.

Year three

The goal of the project in year three was to make it more sustainable (and to continue with a substantially smaller budget). Instead of attempting to provide workshops to all the students, we provided workshops to the instructors prior to the course in the hopes that they would gain more skills and more fully integrate the arts/multimedia approaches into their sections. We also attempted to provide more discipline-specific examples of how these approaches might be integrated into the 
secondary curriculum. For instance, we provided descriptions of how to integrate soundscapes across the curriculum. We also provided support during the course where possible.

\section{Instructor interviews.}

We asked the instructors five questions as a way to engage them in a dialogue about the project (See appendix 2). Instructors generally found the workshops to be very helpful but they felt they still needed more time to develop expertise. The various instructors incorporated those approaches that they believed the students had some expertise with, or that they felt most comfortable with themselves, such as creating blogs with their students.

Several of the instructors incorporated soundscape activities into their course sections. For instance, one instructor modelled this approach by bringing in her violin and setting to music the picture book story Faithful Elephants: A true story of animals, people and war (Yukio Tsuchiya and Ted Lewin), and then invited students to set a variety of texts to music. Other instructors introduced their students to GarageBand and encouraged them to create soundscapes for various kinds of texts.

Other instructors conducted video (iMovie) workshops to introduce students to filmmaking, and/or invited students to use video as one possible way to complete assignments (others included digital storytelling, PowerPoint, or traditional presentations or papers).

The instructors reported mostly favourable responses to integrating these arts/multimedia approaches into the course in year two, but also reported interesting critiques. As one instructor noted, some of their students questioned the use of arts and 
multimedia in a language and literacy across the curriculum course, while others wanted to switch into sections in which instructors were more actively using them. Many students resisted PowerPoint in particular; among other things, they felt it was more performance than teaching.

One instructor invited students to use PowerPoint or video media to advertise to the rest of the class a literacy strategy they might use across the curriculum. As she stated, "the concept was to "sell" others on using the product/strategy." We include excerpts from two examples - one that was meant to "sell" the idea of using picture books across the curriculum, and one meant to "sell" silent reading:

\section{Click here to view Video Clips from Silent Reading and Picture Book Parodies}

What is interesting is the way this medium and assignment (genre) invites parody. We would argue that this is in part because so much of what these students watch is full of satire -- humour, irony, and parody (Jon Stewart's The Daily Show being one of the favoured sources of news among this age group). According to Ian Johnston (1998), satire may be used as "a particular use of humour for overtly moral purposes," a phenomenon also noted in cartoons such as The Simpsons and other 'lampooning' style news such as "The Colbert Report."

When given an assignment that is perceived to be incongruous with student views for teaching and learning (e.g., somewhat contrived), students may see an opportunity to parody the task. This serves the dual purpose of understanding its curricular intention, while recognizing its limitations. As Johnston (1998) explains, "What sets satire apart from normal comedy... is that in satire there is usually a clear and overt didactic intention, a clear moral lesson is the unifying power of the work" (Section B, unpaged). 
The instructor reported a mixed response to the end results: "The students were all amused by each others ads...a few really stood out to them. They laughed and had a good time. I just felt the "tone" of the ads was a little bit disparaging of the content - but maybe I'm just too sensitive. They certainly participated." We would argue that there was a potential space opened here to begin to examine both the power of using dominant cultural forms (e.g. advertising techniques and parody) to critique pedagogical methods, and the limitation if the experience is not exploited to further reflect on, critique and transform literacy pedagogy in schools.

\section{Conclusions and Implications}

As stated above, our youth live in an increasingly multimodal landscape, yet their schooling experiences are often limited to traditional language and literacy discourses and practices. A growing number of researchers are exploring emergent and alternate forms of literacy among youth (Lewis and Fabbo, 2005; Meacham, 2003; Leander, 2003; Schofield and Rogers, 2004), yet few studies have looked at the possibilities of working with pre-service teachers to develop their skills and approaches to using arts and multimedia in their teaching, and to encourage broader and more critical views of literacy and discourse across the disciplines.

We began with these lofty goals of transforming notions of literacy among preservice teachers and encouraging them to explore new possibilities of play and critique. While there is evidence that prospective teachers did, in general, expand their notions of literacy and engage playfully and critically with arts and media, they were also, at times, sceptical and critical of technology and even used it to parody aspects of the course content, such as the use of reading strategies across the curriculum. At the same time, 
their comments reflected their impressive commitment to engaging in technology as a way to be more inclusive -- to make the classroom a more motivating and engaging site of learning for all students.

We can safely conclude that prospective teachers from all disciplines were open to productively drawing on their own and their students' cultural knowledge and multimedia expertise, and to the possibilities for teachers and students to engage in imaginative and critical uses of multiple literacy practices. Our view is that it is important to draw on teachers' and students' abilities and interest in producing arts and media as tools for learning, and to see production and consumption as integral in the authoring of new genres and forms of communication. And more specifically, we feel these approaches are key to rethinking traditional courses in language and literacy across the curriculum.

As we continue with this work, we hope to deepen the methodologies to include a combination of critical media practices and media production in order to provide spaces for instructors and pre-service teachers to create and critique the uses of media and discourses in society. We might also pay more attention to identity representations and ways of using arts and media to open up spaces for productive critiquing of schooling and society within the secondary classroom. For now, we hope this exploratory project will extend the conversation about the potential use of alternative modes of meaning making and multiple literacies in the teacher education curriculum in literacy. 


\section{References}

Alvermann, D., \& Moore, D. (1991) Secondary school reading. In R. Barr, M.L. Kamil, P. Mosenthal, \& P.D. Pearson (Eds.), Handbook of reading research, Vol. 2 (pp. 951-983). New York: Longman.

Begoray, D. (2002). Not just reading anymore: Literacy, community and the pre-service teacher. English Quarterly, Vol. 34 (3\&4), 39-45.

Begoray, D.L. (2003). Sign, sign, everywhere a sign: Multiplying literacies in the preservice language arts curriculum. In CM. Fairbanks, J. Worthy, B. Maloch, J.V. Hoffman, \& D.L. Schallert (Eds.) 52nd Yearbook of the National Reading Conference (pp. 128-138). Oak Creek, WI: National Reading Conference.

Bakhtin, M.M. (1986). Speech genres and other late essays. Austin, Texas: University of Texas Press.

Bean, T.W., Bean, S.K., \& Bean, K.F. (1999). Intergenerational conversations and two adolescents' multiple literacies: Implications for redefining content area literacy. Journal of Adolescent \& Adult Literacy, 42(6), 438-448.

Cuban, L. (2006). Laptops Transforming Classrooms: Yeah, Sure Teachers College Record, Date Published: October 31, 2006 http://www.tcrecord.org. ID Number: 12818. Retrieved November 11, 2006.

Berghoff, B. (1998). Multiple sign systems and reading. The Reading Teacher, 51(6), $520-523$.

Cope, B., \& M. Kalantzis (Eds.). (2000). Multiliteracies: Literacy learning and the design of social futures (pp. 9-37). London: Routledge. 
Gouzouasis, P., \& LaMonde, A. (2004). Classroom Uses of Wireless and Portable Technologies in an arts-based teaching and learning model. International Journal of Learning, 11.

Gouzouasis. P., LaMonde, A., \& M. Guhn. (in press, 2007). The Fine Arts and Media in Education Project: The integration of creative arts-based activities, wireless technologies, and constructivist teaching practices in practicum classrooms. Beynon, C.A. \& Veblen, K. K. with De Alwis, U. \& Horsley, S. (Eds.) Music education in Canada: What is the state of the art? London, ON: Althouse Press of University of Western Ontario.

Jewitt, G., \& Kress, C. (2003). Multimodal literacy. London: Peter Lang

Johnston, I. (1998). A brief introduction to restoration and eighteenth century satire. Retrieved November 23, 2006, from http://www.mala.bc.ca/ Johnstoi/Eng200/satire3.htm

King, J.R., \& O'Brien, D. (2004). Adolescents' multiliteracies and their teachers' need to know: Toward a digital détente. In Alvermann, D. (Ed.), Adolescents and Literacies in a Digital World. New York: Peter Lang.

Kress, G. (2003). Literacy in the New Media Age. London and New York: Routledge.

Leander, K.M. (2003). Writing travelers' tales on New Literacyscapes. [New Directions in Research]. Reading Research Quarterly, 38 (3), 392-397.

Lewis, C., \& Fabos, B. (2005). Instant Messaging, literacies and social identities. Reading Research Quarterly, 40 (4), 470-501.

Luke, A. (2004). Literacy and Educational Fundamentalism: An interview with Allan Luke. English Quarterly, 36 (4). 
Luke, C. (2002). Re-crafting media and ict literacies. In D. Alvermann (Ed.), Adolescents and literacies in a digital world (pp. 132-146). New York: Peter Lang.

New London Group. (1996). A Pedagogy of multiliteracies: Designing social futures. Harvard Educational Review, Vol. 66 no. 1, 60-92.

Manovich, L. (2001) The language of new media. Cambridge, MA: The MIT Press.

Poyntz, S.R. (2006). Independent media, youth agency and the promise of media education. Canadian Journal of Education, 29 (1), 154-176.

Siegel, M. (2006). Rereading the signs: Multimodal transformations in the field of literacy education. Language Arts, 84 (1), 65-77.

Tsuchiya, Y., \& Lewin T. (1977). Faithful elephants: A true story of animals, people and war. Boston, MA: Houghton Mifflin.

Rogers, T., \& Schofield, A. (2005). Things thicker than words: Portraits of youth multiple literacies in an alternative secondary program. In J. Anderson, M. Kendrick, T. Rogers, \& S. Smythe (Eds.), Portraits of Literacy across Families, Schools and Communities. Intersections and Tensions (pp. 205-220). Lawrence Erlbaum Publishers.

Rogers, T., \& Winters, K. (2006). Using multimedia to support the academic lives and literacies of stuggling youth. Language and Literacy Researchers of Canada. Canadian Society for Studies in Education (CSSE), York, Ontario, Canada.

Schofield, A. \& Rogers, T. (2004). At play in fields of ideas: Teaching, curriculum and the lives and multiple literacies of youth. Journal of Adolescent and Adult Literacy, 48 (3), 238- 248. 
Sefton-Green, J. (2006). Youth, Technology and Media Cultures. In J. Green \& A. Luke (Eds.), What counts as learning, What learning counts: Review of Research in Education (pp. 279-306). Washington, DC: American Educational Research Association.

Winters, K., Rogers, T., \& Schofield, A. (2006). The Antigone Project: Using drama and multiple literacies to support print literacy among youth. In J. Schneider, T. Crumpler, \& T. Rogers. (Eds.), Process drama as an educational tool for multiple literacies, p. 35-51. Portsmouth, N.H.: Heinemann.

Gouzouasis. P., LaMonde, A., \& M. Guhn. (in press, 2007). The Fine Arts and Media in Education Project: The integration of creative arts-based activities, wireless technologies, and constructivist teaching practices in practicum classrooms. Beynon, C.A. \& Veblen, K. K. with De Alwis, U. \& Horsley, S. (Eds.) Music education in Canada: What is the state of the art? London, ON: Althouse Press of University of Western Ontario.

Jewitt, G. and Kress, C. (2003) Multimodal literacy. London: Peter Lang

Johnston, I. (1998). A brief introduction to restoration and eighteenth century satire. http://www.mala.bc.ca/ Johnstoi/Eng200/satire3.htm. Retrieved Nov. 23rd, 2006.

King, J. R. \& O’Brien, D. (2004) Adolescents' multiliteracies and their teachers' need to know: Toward a digital détente. In Alvermann, D. (Ed.) Adolescents and Literacies in a Digital World, pp New York: Peter Lang.

Kress, G. (1998) Visual and verbal modes of representation in electronically mediated communication: the potentials of new forms of texts. In I. Snyder (ed.) Page to Screen: taking literacy into the electronic era. London: Routledge. 
Kress, G. (2003). Literacy in the New Media Age. London and New York: Routledge.

Lankshear, C. and Knobel, C. (2003). New literacies: Changing knowledge and classroom learning. Buckingham: Open University Press.

Leander, K. M. (2003). Writing travelers' tales on New Literacyscapes. [New Directions in Research]. Reading Research Quarterly, 38 (3), 392-397.

Lewis, C. and Fabos, B. (2005). Instant Messaging, literacies and social identities. Reading Research Quarterly, 40 (4), 470-501.

Luke, A. (2004) Literacy and Educational Fundamentalism: An interview with Allan Luke. In English Quarterly 36 (4).

Luke, C. (2002) Re-crafting media and ict literacies. In D. Alvermann (Ed.) Adolescents and literacies in a digital world (pp. 132-146. New York: Peter Lang.

New London Group (1996) A Pedagogy of multiliteracies: Designing social futures. Harvard Educational Review, Vol. 66 no. 1, pp 60-92.

Manovich, L. (2001) The language of new media. Cambridge, MA: The MIT Press.

Poyntz, S. R. (2006). Independent media, youth agency and the promise of media education. Canadian Journal of Education, 29 (1), pp 154-176.

Siegel, M. (2006). Rereading the signs: Multimodal transformations in the field of literacy education. Language Arts, 84 (1). September, pages 65-77.

Tsuchiya, Y. and Lewin T. (1977). Faithful elephants: A true story of animals, people and war. Boston, MA: Houghton Mifflin.

Rogers, T. and Schofield, A. (2005). Things thicker than words: Portraits of youth multiple literacies in an alternative secondary program '. Portraits of Literacy across Families, Schools and Communities. Intersections and Tensions. Jim 
Anderson, Maureen Kendrick, Theresa Rogers and Suzanne Smythe (Eds)

Lawrence Erlbaum Publishers, pp 205 - 220.

Rogers, T. and Winters, K. (2006). Using multimedia to support the academic lives and literacies of stuggling youth. Language and Literacy Researchers of Canada; Canadian Society for Studies in Education (CSSE); York, Ontario, Canada.

Schofield, A and Rogers, T. (2004) At play in fields of ideas: Teaching, curriculum and the lives and multiple literacies of youth. Journal of Adolescent and Adult Literacy. 48 (3), pp 238- 248.

Sefton-Green, J. (2006) Youth, Technology and Media Cultures. In J. Green and A. Luke (Eds) What counts as learning, What learning counts: Review of Research in Education. Washington, DC: American Educational Research Association, pp 279- 306.

Winters, K., Rogers, T. and Schofield, A. (2006). The Antigone Project: Using drama and multiple literacies to support print literacy among youth. Process drama as an educational tool for multiple literacies. Jenifer Schneider, Thomas Crumpler and Theresa Rogers. (Eds.) Portsmouth, N.H.: Heinemann. 


\section{Appendix 1: Questionnaire}

1. Pre-course questionnaire: Please state your understanding of the role of language and literacy(ies) in schools and in society.

1. Post-course questionnaire: How did this course help you to understand the role of language and literacy(ies) in schools and in society?

2. Pre-course questionnaire: What is your understanding of the role of language and literacy(ies) in secondary schools in general, and in your discipline area in particular? 2. Post-course questionnaire: What is your understanding of the role of language and literacy(ies) in secondary schools in general, and in your discipline area in particular?

3. Pre-course questionnaire: What are your reflections on the broader notion of "multiple literacies" (non-print as well as print literacies, including multi-media, visual texts, music, performance, arts-based instruction, etc.) in learning in and out of schools?

3. Post-course questionnaire: What are your reflections on the broader notion of "multiple literacies" (non-print as well as print literacies, including multi-media, visual texts, music, performance, arts-based instruction, etc.) in learning in and out of schools? 4. Pre-course questionnaire: What, if any, multiple literacy approaches to teaching are you familiar with and considering using in your classroom (e.g. range of print genres, visuals, blogging or chatting on line, building webpages, performance or music, video filmmaking, etc)?

4. Post-course questionnaire: What, if any, multiple literacy approaches to teaching are you familiar with and considering using in your classroom (e.g. range of print genres, visuals, blogging or chatting on line, building webpages, performance or music, video filmmaking, etc)? 
5. Pre-course questionnaire: What arts and multi-media skills do you already have and what ones would you like to develop?

5. Post-course questionnaire: What arts and multi-media skills did you develop as part of this course? Please indicate which workshops you participated in (e.g. iMovie, movie montage, soundscape, blogging, e-portfolio, other...) and how it improved your skills.

6. Pre-course questionnaire: Do you think the use of multiple literacies approaches might support student learning in your discipline? If yes, in what ways?

6. Post-course questionnaire: Do you think the use of multiple literacies approaches might support student learning in your discipline? If yes, in what ways?

7. Post-course question only: Please describe the language and print and non-print literacy approaches and activities that were most helpful to you in this course and that you will most likely integrate in your own classroom, and how.

\section{Appendix 2: Instructor interview questions.}

1. How useful were the workshops in terms of training you to use the approaches in your course section?

2. How did you integrate arts/multimedia into your course section (with specific examples)?

3. How successful do you feel the infusion of these approaches into your section were?

4. Can you describe student learning and outcomes in the section (with specific examples)?

5. Can you suggest ways to improve future workshops? 